\title{
$810 \mathrm{~m} / \mathrm{min}$ エレベーター 非常止め装置用摩擦材
}

\section{岡田亮二*1) 山田 俊 宏2) 筫河原 準*}

\section{1. 緒言}

ビルの超高層化に伴い，ビル内の垂直輸送手段であるエレ ベーターの高速化はますますその必要性を増している。エレ ベーターの高速化は, 駆動機器, 制御機器ばかりでなく, 安 全装置も性能向上を必要とし，特に速度の 2 乗に比例する 運動エネルギを持つかごを停止させる非常止め装置は，その 性能向上が不可欠である.

従来用いられてきた鋳鉄を中心とする鉄系材料では，800 $\mathrm{m} / \mathrm{min}$ を超える速度では制動が困難になると予測(1)され， 特殊セラミックスを摩擦材に用いた非常止め装置が開発され ている(2).

今回, $810 \mathrm{~m} / \mathrm{min}$ といら超高速のエレベーターを開発す るため, 従来を大幅に上回る運動エネルギを持つかごを安定 に制動でさる非常止め装置用摩擦材の開発を進めた ${ }^{(3)}$. 開発 した摩擦材の特性と, 開発した摩擦材を用いた非常止め装置 の性能について報告する.

\section{2. 非常止め装置の課題 \\ （1）非常止め装置の構造}

非常止め装置とはロープが破断し，かごが落下した場合， 乗客の安全を確保するため，平均減速度が $0.35 \sim 1 \mathrm{G}$ の範囲 で落下する乗りかごを停止させる安全装置である．図 1 は非 常止め装置構造の概略を示す. 非常止め装置は通常かごの下 端部に 2 台 (1 組)設置されて拈り，かごが最高速度を超光所

\footnotetext{
* 株式会社日立製作所

機械研究所 : 1) 主任研究員 2) センター長

水戸工場：3)主任技師

Braking Materials for Emergency Stop Device of Super High Speed Elevator $(810 \mathrm{~m} / \mathrm{min})$; Ryoji Okada, Toshihiro Yamada, Jun Sugahara (Hitachi, Ltd.)

1995年 1 月 25 日受理
}

定の速度に達すると，〈さび状の摩擦材が壁に固定されたレ 一ルをはさみ込み, 落下するかごを摩擦によって停止させる 構造である.

\section{(2) 非常止め装置の課題}

図 2 は各種仕様から試算した非常止め装置が制動すべきエ ネルギ(制動エネルギと称する)を比較した結果である。最高 速度が $810 \mathrm{~m} / \mathrm{min}$ のエレベーターでは非常止め装置の動作 速度が $950 \mathrm{~m} / \mathrm{min}$ を超え，制動エネルギは非常に大きくな る. その結果, 従来の鉄系材料では摩擦熱と摩耗によって落 下するかごを安定に停止させることが困難となって扣り ${ }^{(1)}$, 特性の優れる摩擦材の開発が求められていた.

\section{3. 摩擦材の開発}

(1) 検討材料

非常止め装置用摩擦材には高摩擦係数，耐摩耗性が求めら れ，制御エネルギが大きくなると耐熱性が必要となる。さら に, 人命を守る安全装置の部材であるため, 摩擦係数の安定 性，靶性，加工性などの特性が不可欠である。

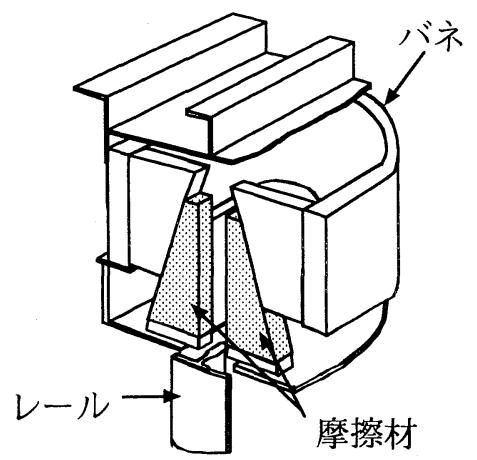

図 1 非常止装置. 


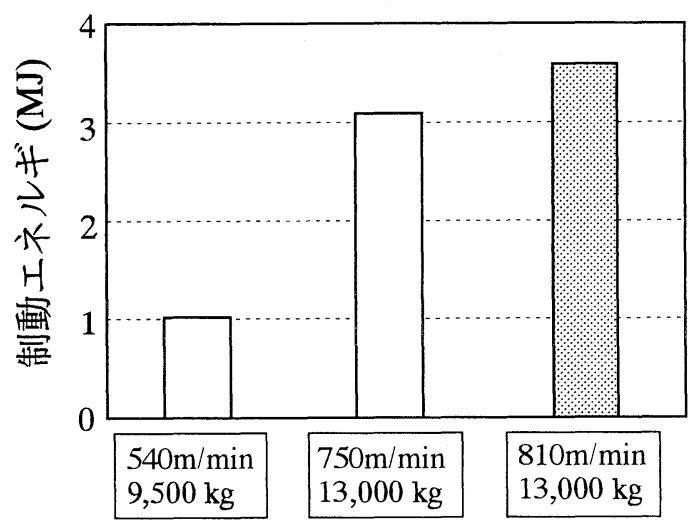

図 2 制動エネルギの比較.

そこで，筆者らは耐熱性は劣るものの摩擦係数の安定性, 靱性, 加工性に優れ，従来非常止め装置摩擦材として実績の 有る鋳鉄を中心に検討した. しかしながら，前述のごとく従 来の鋳鉄では, 図 2 に示すよらな $3 \mathrm{MJ}$ を超える制動エネル ギは，摩擦熱の影響によって安定に制動することは困難であ る. そのため, 耐熱性の改善を中心に $\mathrm{Cr}, \mathrm{Ni}, \mathrm{P}$ を添加した 鋳鉄を試作して摩擦特性を評価し, 最適な組成・組織の鋳鉄 を決定した。

\section{(2) 摩擦試験機と試験条件}

図 3 は試作材の評価に用いた摩擦試験機の概略を示す. 本 試験機はレール材料である SS400 で制作した円盤状の試験 片 TP2 ( $6720 \mathrm{~mm})$, 試作鋳鉄で制作したピン状の試験片 TP1，TP1をTP2 に押し付け移動させるXテーブル， Y テーブル，さらに駆動系と測定制御系から構成される(4).

試験は，回転するTP2 の回転を減速させ, 非常止め装置動作時の減速する速度変化 を模擬する.この間の停止に至るむでの TP1の押し付け力, $\mathrm{TP} 1$ と $\mathrm{TP} 2$ との間の摩擦力, 回転数, 摺動半径を測定し, 摩擦速度と摩擦係数々の相関を測定した。試験条件は 810 $\mathrm{m} / \mathrm{min}$ エレベーター用非常止め装置の動作条件から設定し た．表 1 に試験条件をまとめる.

\section{(3) 開発摩擦材の特性 $(5)$}

図 4 は上記摩擦試験で決定した摩擦特性の最も優れた材料 (以後, 開発材と称する) と, 従来摩擦材の一つである FC250 の, 摩擦開始から停止に至る摩擦係数の変化を示す. 開発材はFC250 と異なり，摩擦直後の摩擦係数の低下が認 められず，変動が少なく高く安定した值を示す。

図 5,6 は摩擦試験機結果から求めた平均摩擦係数と比摩 耗量を FC250の值と1.0として相対值で示したものである. 開発材は FC250 に比較し, 平均摩擦係数が約 1.5 倍, 比摩耗 量が約 $1 / 100$ 優れた特性を示す。
表 1 摩擦試験条件.

\begin{tabular}{c|c}
\hline \hline 面 & $6 \sim 10 \mathrm{~kg} / \mathrm{mm}^{2}$ \\
\hline 摩擦速 度 & $10 \sim 16 \mathrm{~m} / \mathrm{s}$ \\
\hline 減 速 度 & $6 \sim 10 \mathrm{~m} / \mathrm{s}^{2}$ \\
\hline
\end{tabular}

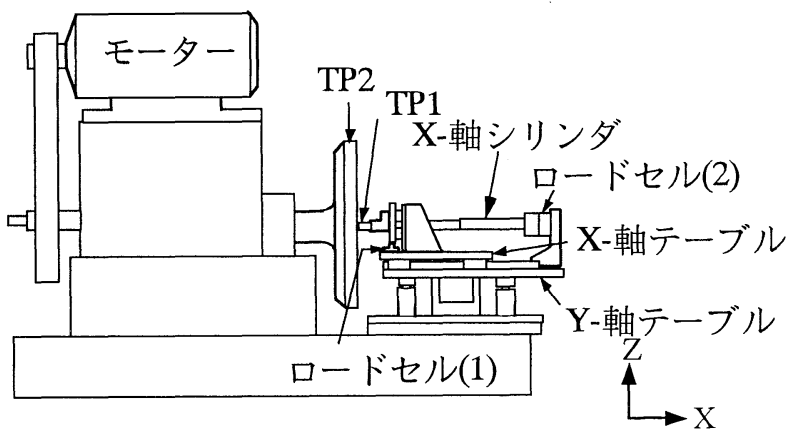

図 3 摩擦試験機.

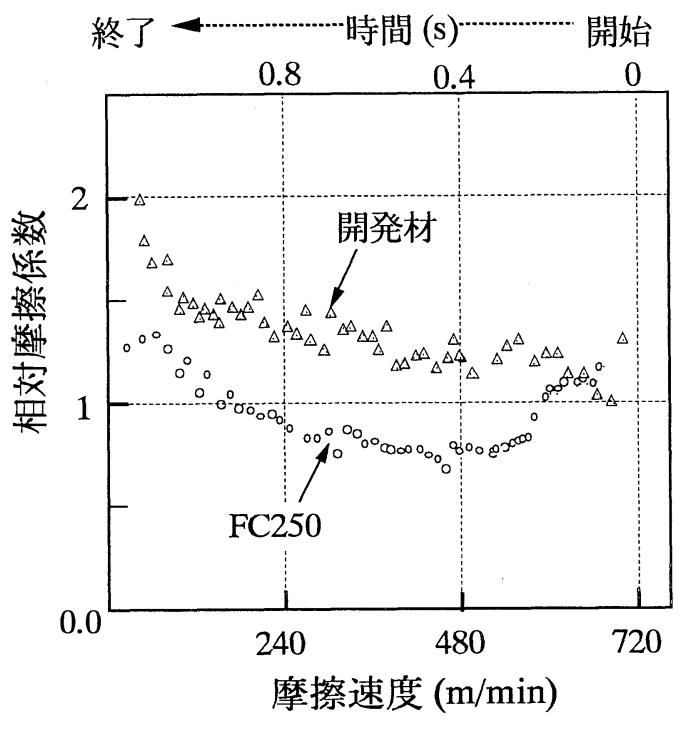

図 4 摩擦係数の変化.

\section{4. 落下試験による確認}

開発した摩擦材を採用した非常止め装置を用いて，実機エ レベーターと同等の動作条件で性能を確認する落下試験を行 い，最終性能を確認した．図 7 は落下試験結果の一例を示 す.この結果は全重量が $13000 \mathrm{~kg}$ となる錘を積載したかご を約 $40 \mathrm{~m}$ の高さから落下させ， $964 \mathrm{~m} / \mathrm{min}$ に達した時点で 非常止め装置を動作させて，落下するかごを停止させた際の 速度変化である。

摩擦材とレールとが摺動した摩擦跡から求めた摺動距離を 用いて算出した平均減速度は $0.76 \mathrm{G}\left(7.45 \mathrm{~m} / \mathrm{s}^{2}\right)$ であり，か ごの傾きとともに国内規格拉よびANSI(American National Standards Institute) 規格の規定範囲内である. 


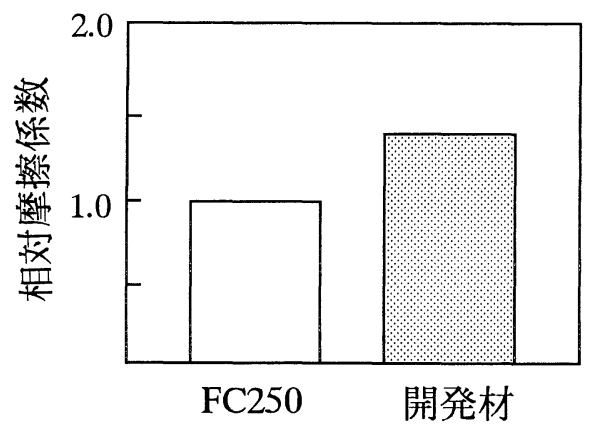

図 5 摩擦係数の比較.

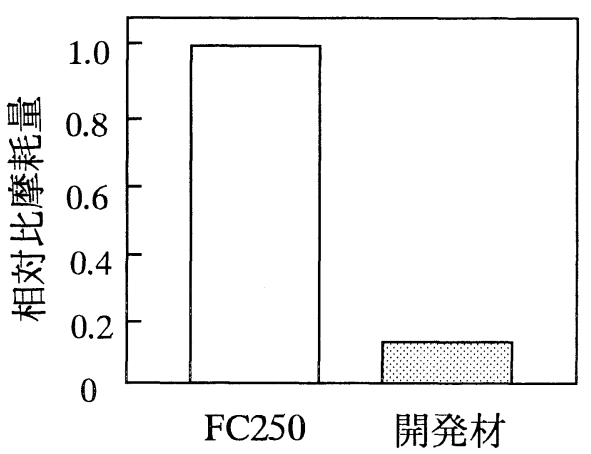

図 6 比摩耗量の比較.

図 8 は，上記落下試験に抢ける摩擦係数の変化を示す。摩 擦係数は変動が少なく, 安定した特性を示し, 摩擦試験機で 求めた特性と注汪一致している.

また本非常止め装置は，540 m/min エレベーター用非常 止め装置の制動エネルギの 3 倍以上である約 $3.5 \mathrm{MJ}$ を保証 し,さらに装置質量の軽量化を達成している.

\section{5. 結言}

(1) $\mathrm{Cr}, \mathrm{Ni}, \mathrm{P}$ の添加によって高温強度の低下を防ぎ， FC250 飞比較して平均摩擦係数約 1.5 倍, 比摩耗量約 $1 / 10$ の 鋳鉄を開発した。

（2）開発材を採用した非常止め装置を用いて落下試験を行 い, $13000 \mathrm{~kg}$ の落下質量を $964 \mathrm{~m} / \mathrm{min}$ の速度から所定減速 度で停止させることができた．かごの傾きとともに国内規格 扣よび ANSI 規格の規定範囲内であることを確認した。

(3) $540 \mathrm{~m} / \mathrm{min}$ エレベーター用非常止め装置の制動エネ ルギの 3 倍以上を保証し, さらに軽量化を達成した高性能

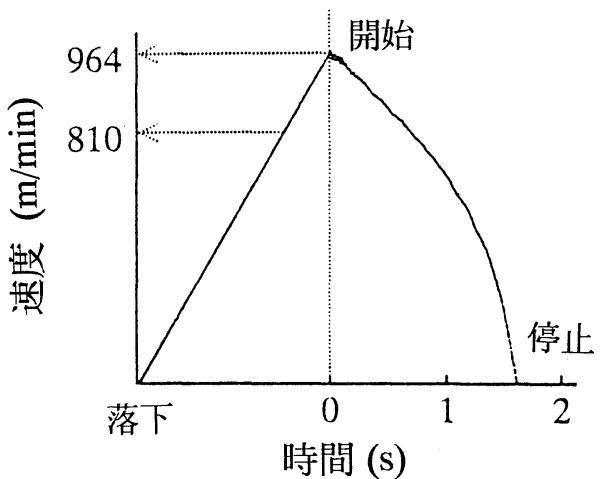

図 7 落下試験結果.

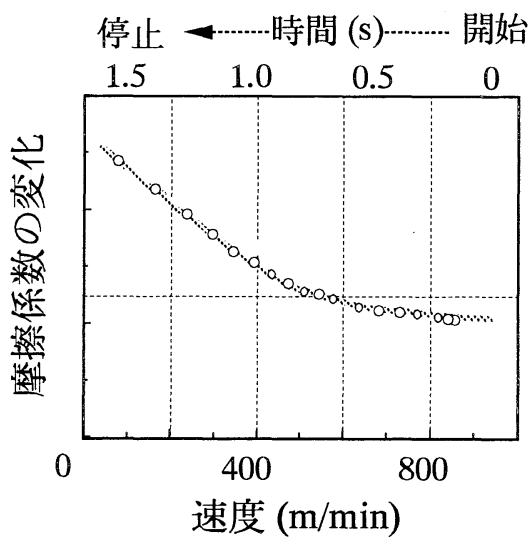

図 8 落下試験に扝ける摩擦係数.

非常止め装置を実現した。

（4）摩擦材と非常止め装置に関連し，特許10件を出願し ている.

\section{文献}

（1）岡田亮二, 岡田克巳, 吉田忠弘, 土方明躬：潤滑， 24,1 (1979) 27.

（2）杉田和彦, 西村信寛, 岡田浩二：日本機械学会(No. 930-6)講 演会講演論文集，(1993)，37.

(3) 重田政之, 目黒都志雄, 稲葉博美, 岡田亮二：日立評論, $\mathbf{7 5}(1993.7), 7$.

（4）岡田亮二, 䇥河原 準, 田中正勝 : 日本金属学会秋期大会講演 概要集, (1993), 225.

（5）岡田亮二，山田俊宏，簧河原 準：日本機械学会(No. 940-57) 講演会講演論文集，(1994), 183. 